\title{
COUNSELING IN INCREASING HEALTH LITERACY CONCERNING KNOWLEDGE ON ADOLESCENT REPRODUCTIVE HEALTH IN JAKARTA
}

\author{
Ni Nyoman Sri Artina Dewi ${ }^{1 *}$ Agustina Ida Pratiwi ${ }^{2}$ \\ ${ }^{1,2}$, STIK Sint Carolus, Jl.Salemba Raya 41, Jakarta 10440, Indonesia
}

\section{INFORMASI ARTIKEL:}

\section{Riwayat Artikel:}

Tanggal diterima: Maret 2020

Tanggal di revisi: Maret 2020

Tanggal di Publikasi: April 2020

Key Word : adolescents, health literacy, counseling, knowledge, reproductive health

\begin{abstract}
A B S T R A C T
Health literacy is a very important part in increasing adolescent knowledge about reproductive health. This can be directed, one of them, by counseling. With various problems experienced by adolescents, this study aimed to see whether counseling given to adolescents in an area in central Jakarta, Indonesia, could provide significant results. This pre-experimental study recruited 28 adolescents to be given pretest and posttest with the theme of adolescent reproductive health. With validity and reliability tests conducted, the teenagers were given a questionnaire about reproductive health between the pretest and posttest, with intervention given in the form of counseling between the two tests. The results shown were that there was a significant difference between pretest and posttest done by the respondents after counseling was given to increase reproductive health literacy with a value of $\mathrm{p}<0.05$.
\end{abstract}

\section{INTRODUCTION}

Adolescence is often considered a health period that faces certain health risks, especially those related to reproduction and sexuality. These problems include problems with emotional changes due to body changes with the onset of puberty, problems related to menstruation, initiation of premature sex, unwanted pregnancy, to unsafe abortion. Diseases such as the human immunodeficiency virus (HIV) also threaten the lives of adolescents when relationships are not well directed (Denno, Hoopes, \& Chandra-Mouli, 2015).

Sexually active adolescents can increase the risk of sexually transmitted infections (STIs), including HIV mentioned above. Unwanted pregnancies and childbirth will also aggravate adolescents, both men and women, when information about reproductive health does not reach them. This means that adolescents have limitations and, in some places, do not have access to education and contraception in sexual and reproductive health, making teenage girls more vulnerable to early and unwanted pregnancy (Salam, et al., 2016).
Reproductive health is one of the important areas in adolescent health (Morris \& Rushwan, 2015). Changes in circumstances are very rapid due to urbanization, early maturity of the physical youth, behavior changes, increased international mass media penetration which increases adolescent sexual behavior and wrong policies from parents result in adolescent reproductive health problems.

All young people should have the right to access comprehensive sexual and reproductive health information and services. This will make them have the ability to make decisions based on the information they get. However, many adolescents and young people in developing countries do not have access to quality services and information, regardless of the risks and challenges they face (Braeken, Otoo-Oyortey, $\&$ Serour, 2007).

A pornographic addiction screening survey conducted in DKI Jakarta and Pandeglang showed $96.7 \%$ had been exposed to pornography and $3.7 \%$ had experienced pornographic addiction (SDKI, 2017). Considering that there are still many teenagers 
who do not understand reproductive health, it is very important to do counseling about adolescent reproductive health in the hope that adolescents can change their knowledge and attitudes by improving health literacy among them by the sake of improved knowledge.

\section{METHOD}

This pre-experimental study used primary data obtained from the results of a questionnaire about adolescent knowledge on reproductive health with one group pretest-posttest study design. The independent variable was adolescent reproductive health counseling while the dependent variable was the level of adolescent knowledge about reproductive health. The samples in this study were recruited from the area of the Central Jakarta, Indonesia using accidental total sampling, with a total of 28 teenage respondents. The type of data collected in this study was primary data obtained directly from study subjects, namely data on the level of adolescent knowledge about adolescent reproductive health obtained from questionnaire sheets that had been filled out by the adolescents.

In this study the instrument employed by the researchers was a questionnaire used to retrieve primary data. To find out whether the questionnaire was able to measure what was being measured, a validity test was performed. Retrieval of the questionnaire was carried out by means of a canvasser, which is data that is filled in and awaited by the researcher. Product Moment was used to test between correlation and one shot was used to test reliability. The Likert scale was used for the questionnaire with Cronbach's Alpha as a test technique. Data processing was done by a series of editing, coding, entry, and cleaning processes. For analysis, this study used univariate analysis and bivariate analysis with the Wilcoxon test.

\section{RESULT AND DISCUSSION}

The respondents' age ranged from 10 to 18 years old. Based on the gender, the female respondents were 11 adolescents while the men ones were 17 persons. From the pretest done by the respondents on adolescent reproductive health, those who had bad level of knowledge were 11 persons or 39.3 percent while 17 persons $(60.7 \%)$ were categorized to have a good level of knowledge (Table 1). This means that the health literacy level in the category of bad knowledge was still high.

\section{Tabel 1}

Adolescents' health literary on knowledge about reproductive health before counseling at pretest

\begin{tabular}{lllc}
\hline \multicolumn{3}{c}{ Pretest } & \\
\hline No & Category & (n) & $\mathbf{( \% )}$ \\
\hline $\mathbf{0}$ & Bad & $\mathbf{1 1}$ & $\mathbf{3 9 . 3}$ \\
$\mathbf{1}$ & Good & $\mathbf{1 7}$ & $\mathbf{6 0 . 7}$ \\
& Total & $\mathbf{2 8}$ & $\mathbf{1 0 0}$ \\
\hline
\end{tabular}

The results were quite different on the posttest when there was a decreased number in the category of bad level of knowledge and an increased number in the good category (Table 2). The health literacy improved among the adolescents, showing that the counselling program had showed its effectiveness.

\section{Tabel 2}

Adolescents' health literary on knowledge about reproductive health before counseling at posttest

\begin{tabular}{lllr}
\hline \multicolumn{4}{c}{ Posttest } \\
\hline No & Category & (n) & $(\%)$ \\
\hline 0 & Bad & 9 & 32.1 \\
1 & Good & 19 & 67.9 \\
& Total & 28 & 100 \\
\hline
\end{tabular}


All samples were included by counting the left blank answers as incorrect answers. From the data normality test using the Shapiro-Wilk method, $p>0.05$ was obtained in both the pretest and posttest data, so it could be concluded that both data had a normal distribution.

\section{Tabel 3}

\section{Distribution of adolescents' health literary on knowledge about reproductive health before and after counseling}

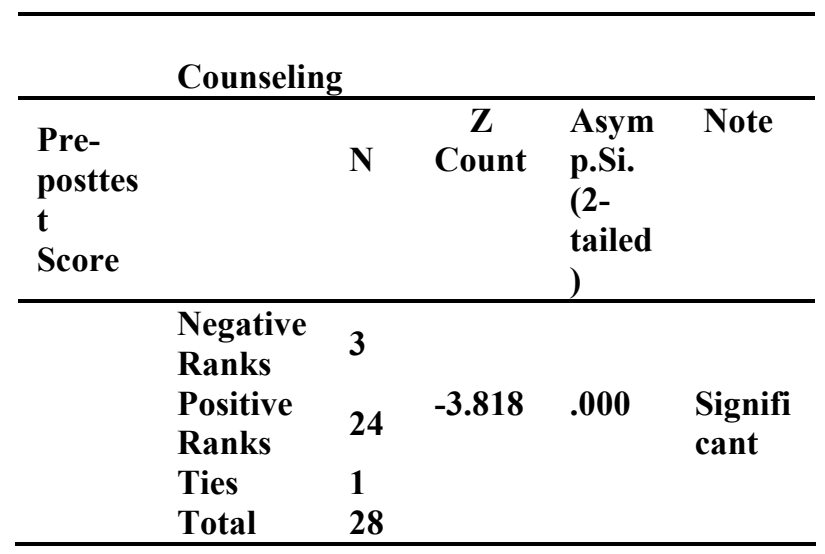

The results of comparison of health literacy on the knowledge before and after counseling showed that there were 3 people with lower level of knowledge after counselling compared to pretest, 24 people with higher postcounselling knowledge, and there was one respondent with fixed knowledge before and after counseling. Wilcoxon Test results showed a significance value (sig) of $0.000(\mathrm{p}<0.05)$, meaning there was a significant difference between the score before counseling with that after counseling.

Basically, there were an increased number of those who improved their knowledge on adolescent reproductive health after the provision of counselling in this study. An increase in knowledge about reproductive health before and after counseling was in accordance with many studies, one of which was a study conducted by Buzarudina (2013) that there was an increase in the average value of respondents regarding reproductive health between before and after counseling.

Counseling in health field is one method that is believed to be able to increase or increase one's knowledge and abilities with the aim of changing or influencing human behavior (behavioral change) individually to be more independent in achieving healthy living goals (Duffy, 2012). Several factors can influence adolescent knowledge about reproductive health apart from the counseling itself, which is seen from the level of formal education and exposure to information both from the mass media, parents, teachers and from health workers. The more information can affect or increase one's knowledge and with knowledge raises awareness that eventually someone will behave and behave in accordance with the knowledge possessed (Notoatmodjo, 2007).

Health education as one of counselling forms can be an intervention that is primarily towards behavioral factors. Education in general is any effort that is planned to influence other people, both individually, in groups, and in society, so that they do what is expected by education practitioners. Elements in education include inputs which are the target of education and educators, processes planned to influence others, and outputs in the form of behavior. Health education is an effort or activity to create community behavior that is conducive to health. Health education makes people aware and know how to take care of their health, avoid and prevent things that are detrimental to health, and so on. This is called 'health literacy' (Batterham, Beauchamp, \& Osborne 2017). Furthermore, public awareness continues to achieve healthy behavior. This means that health is not only to be known and realized, but also to be practiced in everyday life (healthy lifestyle). Health literacy as a concept that recognizes that people have different capacities 
to find, understand, and use health information and it can be formed by, among others, counseling. This will result in different experiences that shape their will and confidence because new information that they may receive will be considered in their minds to change for the better.

\section{CONCLUSION}

Counseling conducted in an area in central Jakarta showed significant results, namely an increase in adolescent knowledge of reproductive health. With these results, counseling activities become an effective means of providing adolescents with good media in increasing their understanding of reproductive health so that negative things that are not desired can be minimized or even eliminated.

\section{REFERENCE}

Batterham, R. W., Beauchamp, A., \& Osborne, R. H. (2017). Health Literacy. International Encyclopedia of Public Health, 428-437. doi:10.1016/b978-0-12-803678-5.00190-9

Braeken, D., Otoo-Oyortey, N., \& Serour, G. (2007). Access to sexual and reproductive health care: Adolescents and young people. International Journal of Gynecology \& Obstetrics, 98(2), 172-174. doi:10.1016/j.ijgo.2007.04.016

Buzarudina, F. (2013). Efektivitas penyuluhan kesehatan reproduksi remaja terhadap tingkat pengetahuan siswa sman 6 kecamatan pontianak timur tahun 2013. Jurnal Mahasiswa PSPD FK Universitas Tanjungpura.

Denno, D. M., Hoopes, A. J., \& ChandraMouli, V. (2015). Effective Strategies to Provide Adolescent Sexual and Reproductive Health Services and to Increase Demand and Community Support. Journal of Adolescent Health, 56(1), S22-S41. doi:10.1016/j.jadohealth.2014.09.012
Duffy, F. D. (2012). Counseling for Behavior Change. Goldman's Cecil Medicine, 50-52. doi:10.1016/b978-1-4377-1604-7.00013-0

Morris, J. L., \& Rushwan, H. (2015). Adolescent sexual and reproductive health: The global challenges. International Journal of Gynecology \& Obstetrics, 131, S40-S42. doi:10.1016/j.ijgo.2015.02.006

Notoatmodjo. (2007). Promosi kesehatan dan ilmu perilaku. Jakarta: Rineka Cipta.

Salam, R. A., Faqqah, A., Sajjad, N., Lassi, Z. S., Das, J. K., Kaufman, M., \& Bhutta, Z. A. (2016). Improving Adolescent Sexual and Reproductive Health: A Systematic Review of Potential Interventions. Journal of Adolescent Health, 59(4), S11-S28. doi:10.1016/j.jadohealth.2016.05.022

SDKI. (2012). Keluarga Berencana Nasional (BKKBN). Jakarta. 